\title{
Completion of the spectroscopical data for the synthesis of DIMBOA
}

\author{
Norbert Handler and Thomas Erker * \\ Department of Medicinal/ Pharmaceutical Chemistry, University of Vienna, \\ Althanstrasse 14, A-1090 Vienna, Austria
}

\begin{abstract}
Cyclic hydroxamic acids like 2,4-dihydroxy-7-methoxy-2H-1,4benzoxazin-3(4H)-one (DIMBOA) and 2,4-dihydroxy-2H-1,4-benzoxazin$3(4 H)$-one (DIBOA) are found in several plants playing an important role in the defense-system of plants against a variety of enemies. To investigate new mechanism and effects we synthesized the molecules using known synthetic pathways. Since the chemical data of DIMBOA are not complete or even false, we decided to publish the missing ones in this journal.
\end{abstract}

\section{Keywords}

Cyclic hydroxamic acid, DIMBOA, chemical data.

\section{Introduction}

Benzoxazinoids are naturally occuring in a variety of plants like Secale cereale L. [1], Triticum aestivum L. or Zea mays L. [2] and especially in many important crop plants of the family Gramineae. These compounds are chemical resistance factors against insects, fungi, bacteria and virus in these plants [3], but inhibitory effects on human cancer cells are also reported [4]. The most important cyclic hydroxamic acids are 2,4-dihydroxy-2H-1,4benzoxazin-3(4H)-one (DIBOA) and 2,4-dihydroxy-7-methoxy-2H-1,4benzoxazin-3(4H)-one (DIMBOA) and so we synthesized the two molecules following known synthetic pathways $[5,6]$. 
<smiles>O=C1C(O)Oc2ccccc2N1O</smiles>

DIBOA<smiles>COc1ccc2c(c1)OC(O)C(=O)N2O</smiles>

DIMBOA

\section{Results and discussion}

The chemical and physical data of DIBOA are reported complete [5] and are identical to our results. On the other hand the synthesis of DIMBOA is not described fully in the current publications.

The first step is the synthesis of 5-methoxy-2-nitrophenol (1) which is also available from commercial suppliers but it is quite expensive and only available in small amounts. Hartenstein and Sicker [7] describe a convenient method starting from 3-methoxyphenol which was nitrosylated and then oxidized to yield the corresponding nitro-product.<smiles>COc1cccc(O)c1</smiles><smiles>COc1ccc([N+](=O)[O-])c(O)c1</smiles>

1

The potassium salt of 1 reacted with methyl 2-bromo-2-methoxyacetate via $S_{N}$-reaction to yield the corresponding acetale 2 . This molecule is quite unstable and only characterized by its melting point in the patent published by Jernow and Rosen [8]. In our work we present the missing data for compound 2.<smiles>COc1ccc([N+](=O)[O-])c(OC)c1</smiles><smiles>CC[C@H](OC(=O)C(C)C)C(C)C</smiles><smiles>COC(=O)C(OC)Oc1cc(OC)ccc1[N+](=O)[O-]</smiles> 
The following reduction was easily managed according to literature [6] with $\mathrm{NaBH}_{4}$ and $10 \%$ palladium on charcoal in water/ dioxane. The nmr data were completed with ${ }^{13} \mathrm{C} \mathrm{nmr}$ values given for the cyclic hydroxamic acid 3 .<smiles>COC(=O)C(OC)Oc1cc(OC)ccc1[N+](=O)[O-]</smiles>

2<smiles>COc1ccc2c(c1)OC(OC)C(=O)N2O</smiles>

3

The demethylation of the acetale 3 was carried out with $\mathrm{BCl}_{3}$ in $\mathrm{CH}_{2} \mathrm{Cl}_{2}$ followed by the reaction with $\mathrm{Ag}_{2} \mathrm{CO}_{3}$ in water/ THF as proposed in literature [6]. Although the yield was poor the desired molecule 4 (DIMBOA) could be obtained and the chemical data could be completed or corrected, respectively, since the mass spectrum of the compound was published wrong.<smiles>COc1ccc2c(c1)OC(OC)C(=O)N2O</smiles>

3

$$
\underset{\text { 2. } \mathrm{Ag}_{2} \mathrm{CO}_{3}}{\stackrel{\text { 1. } \mathrm{BCl}_{3}}{\longrightarrow}}
$$<smiles>COc1ccc2c(c1)OC(O)C(=O)N2O</smiles>

4 (DIMBOA)

In conclusion, we could obtain the desired molecules DIBOA and DIMBOA following the literature and we could complete the physical and chemical data for the synthesis of DIMBOA.

\section{Experimental}

The melting points were determined on a Kofler hot-stage apparatus and are uncorrected. The ${ }^{1} \mathrm{H}$ and ${ }^{13} \mathrm{C} \mathrm{nmr}$ spectra were recorded on a Bruker Avance DPx200. The ppm-values are related to tetramethylsilane as internal standard. The mass spectra were recorded on a Shimadzu QP-5000 mass spectrometer. 


\section{5-Methoxy-2-nitrophenol (1) [7]}

$0.6 \mathrm{~mol}(74.5 \mathrm{~g})$ 3-methoxyphenol and $0.9 \mathrm{~mol}(62.1 \mathrm{~g})$ sodium nitrite are solved in three liter water. The solution is stirred at 0 to $2{ }^{\circ} \mathrm{C}$ under exclusion of light and $250 \mathrm{ml}$ ice-cold $4 \mathrm{~N}$ sulfuric acid are added dropwise within 30 minutes. After another 30 minutes the 5-methoxy-2-nitrosophenol formed is filtered off and suspended in a flask containing 1.5 liter water with exclusion of light at $20^{\circ} \mathrm{C}$. Then 1.5 liter nitric acid $(50 \%)$ is added drop-by-drop within 90 minutes holding the temperatur between 20 and $25^{\circ} \mathrm{C}$. The product formed is filtered off, washed with $100 \mathrm{ml}$ ice-water and recrystallized from methanol yielding $67.2 \mathrm{~g}(66 \%)$ of $1\left(\mathrm{mp} 93-95^{\circ} \mathrm{C}\right) .{ }^{1} \mathrm{H} \mathrm{nmr}\left(200 \mathrm{MHz}, \mathrm{CDCl}_{3}\right): \delta=11.04$ (s, $1 \mathrm{H}, \mathrm{OH}), 8.03$ (d, $J=10.2 \mathrm{~Hz}, 1 \mathrm{H}$, phenyl-H), 6.55-6.49 (m, $2 \mathrm{H}$, phenyl-H), $3.88\left(\mathrm{~s}, 3 \mathrm{H}, \mathrm{OCH}_{3}\right) ;{ }^{13} \mathrm{C} \mathrm{nmr}\left(50 \mathrm{MHz}, \mathrm{CDCl}_{3}\right): \delta=179.0,167.0,157.9,126.9$, 109.4, 101.3, 56.1; ms: $m / e=169\left(\mathrm{M}^{+}, 100 \%\right), 139(39 \%), 111(41 \%)$.

\section{Methyl 2-methoxy-2-(5-methoxy-2-nitrophenoxy)acetate (2) [6]}

$10 \mathrm{mmol}(2.07 \mathrm{~g})$ potassium 5-methoxy-2-nitrophenolate are placed without solvent in a dry three-necked flask and $20 \mathrm{mmol}(3.32 \mathrm{~g})$ methyl 2bromo-2-methoxy-acetate are added dropwise. The suspension is stirred at room temperature for 2 hours and then purified by flash column chromatography using toluene/ ethyl acetate $20+1$ as eluens yielding $1.8 \mathrm{~g}$ $(66 \%)$ of $2\left(\mathrm{mp} 81-82{ }^{\circ} \mathrm{C}\right) .{ }^{1} \mathrm{H} \mathrm{nmr}\left(200 \mathrm{MHz}, \mathrm{CDCl}_{3}\right): \delta=7.98$ (d, $J_{\text {ortho }}=9.1$ $\mathrm{Hz}, 1 \mathrm{H}$, phenyl-H), 6.77 (d, $J_{\text {meta }}=2.4 \mathrm{~Hz}, 1 \mathrm{H}$, phenyl-H), 6.65 (dd, $J_{\text {ortho }}=9.1$ $\mathrm{Hz}, J_{\text {meta }}=2.4 \mathrm{~Hz}, 1 \mathrm{H}$, phenyl-H), $5.57\left(\mathrm{~s}, 1 \mathrm{H}\right.$, acetal-H), $3.87\left(\mathrm{~s}, 3 \mathrm{H}, \mathrm{OCH}_{3}\right)$, $3.85\left(\mathrm{~s}, 3 \mathrm{H}, \mathrm{OCH}_{3}\right), 3.60\left(\mathrm{~s}, 3 \mathrm{H}, \mathrm{OOCH}_{3}\right) ;{ }^{13} \mathrm{C} \mathrm{nmr}\left(50 \mathrm{MHz}, \mathrm{CDCl}_{3}\right): \delta=165.8$,

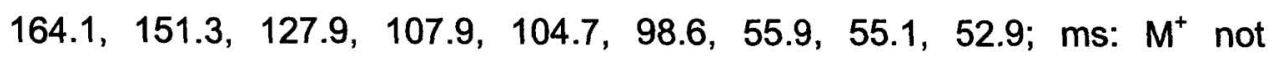
detectable.

\section{2,7-Dimethoxy-4-hydroxy-2H-1,4-benzoxazin-3(4H)-one (3) [6]}

$6.6 \mathrm{mmol}(1.79 \mathrm{~g})$ methyl 2-methoxy-2-(5-methoxy-2nitrophenoxy)acetate (2) is solved in $10 \mathrm{ml}$ dioxane and added drop-by-drop to a rapidly stirring suspension of $1 \mathrm{~g} \mathrm{NaBH}_{4}$ and $0.1 \mathrm{~g} 10 \%$ palladium on charcoal in $80 \mathrm{ml} \mathrm{1:1} \mathrm{water/} \mathrm{dioxane.} \mathrm{The} \mathrm{reaction} \mathrm{temperature} \mathrm{is} \mathrm{kept}$ 
between 15 and $20^{\circ} \mathrm{C}$. After the complete addition of the ester the mixture is stirred for another $\mathbf{3 0}$ minutes, then the catalyst is filtered off and the filtrate is acidified with $1 \mathrm{~N} \mathrm{HCl}$ to $\mathrm{pH} 4$. The solution is extracted immediately three times with ethyl acetate, the combined organic layers are washed with brine, dried with sodium sulfate and evaporated. The raw product is recrystallized from ethanol yielding $0.800 \mathrm{~g}(53.8 \%)$ of $3\left(\mathrm{mp} 149-150{ }^{\circ} \mathrm{C}\right) .{ }^{1} \mathrm{H} \mathrm{nmr}(200 \mathrm{MHz}$, $\mathrm{CDCl}_{3}+\mathrm{d}_{6}$-DMSO): $\delta=10.74$ (s, broad, $1 \mathrm{H}, \mathrm{OH}$ ), 7.23 (d, Jortho $=9.4 \mathrm{~Hz}, 1 \mathrm{H}$, phenyl-H), 6.67-6.60 (m, 2H, phenyl-H), 5.38 (s, $1 \mathrm{H}$, acetal-H), $3.78(\mathrm{~s}, 3 \mathrm{H}$, $\left.\mathrm{OCH}_{3}\right), 3.52\left(\mathrm{~s}, 3 \mathrm{H}, \mathrm{OCH}_{3}\right) ;{ }^{13} \mathrm{C} \mathrm{nmr}\left(50 \mathrm{MHz}, \mathrm{CDCl}_{3}+\mathrm{d}_{6}-\mathrm{DMSO}\right): \delta=157.7$, 156.2, 140.8, 121.8, 113.7, 107.6, 103.0, 98.4, 55.8, 55.1; $\mathrm{ms}: \mathrm{m} / \mathrm{e}=225\left(\mathrm{M}^{+}\right.$, $12 \%), 209$ (100\%), 150 (54\%), 149 (49\%), 134 (24\%).

\section{2,4-Dihydroxy-7-methoxy-2H-1,4-benzoxazin-3(4H)-one (4) [6]}

$3 \mathrm{mmol}(0.675 \mathrm{~g})$ 2,7-dimethoxy-4-hydroxy-2H-1,4-benzoxazin-3(4H)one (3) is suspended in $50 \mathrm{ml}$ dry $\mathrm{CH}_{2} \mathrm{Cl}_{2}$ and cooled to $-50^{\circ} \mathrm{C}$ under argon with card-ice. $9 \mathrm{mmol}$ ( $9 \mathrm{ml} 1 \mathrm{M}$-solution) boron trichloride is added via syringe. The solution is stirred at room temperature for 2.5 hours. After this $8 \mathrm{ml}$ of THF is added and the mixture is given into a seperatory funnel. Then $15 \mathrm{ml}$ water is added, the organic layer is removed, the aqueous layer extracted again with ethyl acetate and the combined organic layers are evaporated without drying to a dark oil. This oil is resolved in $15 \mathrm{ml} \mathrm{THF}$ and the solution is added over 10 minutes to a rapidly stirring suspension of $6 \mathrm{mmol}(1.6 \mathrm{~g})$ silver carbonate in a 2:1 water-THF mixture and stirred for 20 minutes. The suspension is then filtered and extracted with ethyl acetate until the aqueous layer shows no color with $\mathrm{FeCl}_{3}$. The combined organic layers are washed with brine, dried over sodium sulfate and concentrated to $10 \mathrm{ml}$. Then $10 \mathrm{ml}$ hexane is added and the mixture is cooled overnight in a refridgerator. The precipitate is filtered off to yield $0.190 \mathrm{~g}(30 \%)$ of 4 (mp $\left.150-155^{\circ} \mathrm{C}\right) .{ }^{1} \mathrm{H} \mathrm{nmr}\left(200 \mathrm{MHz}, \mathrm{d}_{6}-\mathrm{DMSO}\right): \delta=$ 10.82 (s, broad, $1 \mathrm{H}, \mathrm{OH}), 8.14$ (s, broad, $1 \mathrm{H}, \mathrm{OH}), 7.15\left(\mathrm{~d}, J_{\text {ortho }}=9.1 \mathrm{~Hz}, 1 \mathrm{H}\right.$, phenyl-H), 6.69-6.64 (m, 2H, phenyl-H), $5.65(\mathrm{~s}, 1 \mathrm{H}$, acetal- $\mathrm{H}), 3.72(\mathrm{~s}, 3 \mathrm{H}$, $\left.\mathrm{OCH}_{3}\right) ;{ }^{13} \mathrm{C} \mathrm{nmr}\left(50 \mathrm{MHz}, \mathrm{d}_{6}\right.$-DMSO): $\delta=156.8,156.0,141.6,122.4,113.7$, 
107.6, 103.4, 92.4, 55.5; ms: $m / e=211\left(\mathrm{M}^{+}, 7 \%\right), 165(100 \%), 150(39 \%), 106$ $(17 \%)$.

\section{References}

[1] Virtanen A I, Hietala P K.

2(3)-Benzoxazolinone, an anti-Fusarium factor in rye seedlings.

Acta Chemica Scandinavica 1955;9:1543-44.

[2] Virtanen A I, Hietala P K, Wahlroos O.

An anti-fungal factor in maize and wheat plants.

Suomen Kemistilehti 1956;B29:143.

[3] Niemeyer H M.

Hydroxamic acids (4-hydroxy-1,4-benzoxazin-3-ones), defence chemicals in the gramineae

Phytochemistry 1988;24:2959-62.

[4] Zhang X, Habib F K, Ross M, Ross U, Lewenstein A, Rose K, Jaton J-C. Isolation and characterization or a cyclic hydroxamic acid from a pollen extract, which inhibits cancerous cell growth in vitro Journal of Medicinal Chemistry 1995;38:735-8.

[5] Sicker D, Prätorius B, Mann G, Meyer L.

A Convenient Synthesis of 2,4-Dihydroxy-2H-1,4-benzoxazin-3(4H)-one. Synthesis 1989;211-212.

[6] Attkinson J, Morand P, Arnason J T, Niemeyer H M, Bravo H R.

Analogues of the Cyclic Hydroxamic Acid 2,4-Dihydroxy-7-methoxy-2H1,4-benzoxazin-3-one: Decomposition to Benzoxazolinones and Reaction with $\beta$-Mercaptoethanol.

J. Org. Chem. 1991;56:1788-1800.

[7] Hartenstein H, Sicker D.

An Efficient Synthesis of 5-Methoxy-2-nitrophenol.

J. Prakt. Chemie 1993;335:103-104.

[8] Jernow J L, Rosen P.

2H-1,4-Benzoxazin-3(4H)-ones.

US-Patent Nr. 3,862,180; 21.1.1975. 